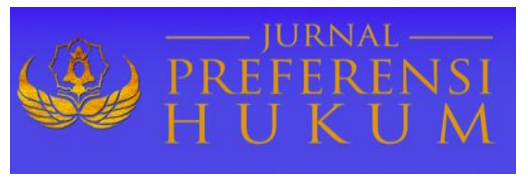

Jurnal Preferensi Hukum | ISSN: XXXX | E-ISSN: XXXX

Vol. 1 No. 1 - Juli 2020 hal. 1-7| Available online at https://www.ejournal.warmadewa.ac.id/index.php/juprehum

\title{
PERLINDUNGAN HUKUM TERHADAP DATA PRIBADI PENGGUNA JASA TRANSPORTASI ONLINE
}

\author{
I Gusti Dama Galang Devara, Anak Agung Sagung Laksmi Dewi, Ni Made Puspasutari Ujianti \\ Fakultas Hukum Universitas Warmadewa, Denpasar-Bali, Indonesia
}

\begin{abstract}
Abstrak
Perkembangan teknologi membawa dampak terhadap segala kegiatan masyarakat, salah satunya ialah adanya layanan tranportasi online seperti yang disediakan oleh Gojek, Grab, Uber, dan yang lainnya yang tidak hanya menyediakan layanan transportasi tetapi juga layanan antar-jemput barang, makanan dan yang lainnya. Menggunakan jasa transportasi online mensyaratkan pengguna memiliki aplikasinya dan mendaftarkan diri mereka. Akan tetapi, data pribadi pengguna jasa tersebut sering disalahgunakan oleh para pengemudi (driver) untuk alasan dan tujuan tertentu. Untuk mengatasi dan mengantisipasi hal ini, suatu pegaturan hukum yang khusus yang menjadi payung hukum untuk melindungi setiap pengguna dari penyalahgunaan data pribadinya oleh driver. Kajian ini menelaah bentuk perlindungan hukum bagi pengguna jasa transportasi online yang dilakukan dalam desain penelitian hukum normatif dengan memanfaatkan pasal dan ayat undang-undang tentang transportasi dan beberapa undang-undang terkait lainnya. Hasil kajian menunjukkan bahwa perlindungan hukum bagi pengguna jasa transportasi online dari penyalahgunaan data pribadinya berbentuk perlindungan hukum represif. Penggunajasa transportasi online dapat mengajukan gugatan perdata kepada pihak penyelenggara jasa transportasi online dan juga dapat mengajukan gugatan pidana tentang tindakan pengendara/pengemudi secara langsung kepada pengendaranya tanpa beratasnamakan penyedia jasa transportasi online. Upaya penyelesaian kasus penyalahgunaan data pribadi pengguna jasa transportasi online yang menimbulkan sengketa dapat dilakukan melalui musyawarah, arbitrase dan pengadilan. Ketiga penyelesaian sengketa ini sesuai dengan Pasal 45Ayat (1), (2) UUPK dan Pasal 6 UU Arbitrase. Mengenai tindakan pembatalan penggunaan jasa transportasi online secara semena-mena oleh pengguna jasa adalah sebuah objek yang penting dikaji menurut tataran hukum dalam penelitian selanjutnya.
\end{abstract}

Kata Kunci: Data Pribadi; Perlindungan Hukum; Transportasi Online

\begin{abstract}
Technological developments have brought an impact on all community activities, one of which is the emersion of online transportation services such as those provided by Gojek, Grab, Uber, and others which do not only provide the services of riding but also the services of the delivery of goods, food and others. Using online transportation services requires users to download the application and register themselves. However, the personal data of the service users are often misused by drivers for certain reasons and purposes. To overcome and anticipate this, a strict legal regulation appearing as the legal umbrella to protect each online transportation user from misuse of their personal data by the driver is necessary. This study examines the forms of legal protection for users of online transportation services. Conducted in the design of normative legal research, the study makes use of articles and paragraphs of the laws on transportation and several other related laws. The results of the study indicate that legal protection for users of online transportation services from misuse of their personal data takes the form of repressive legal protection. Online transportation service users are permitted to file a civil suit to the online transportation service provider and to file a direct criminal suit regarding the acts of the driver, not on behalf of the online transportation service provider. Efforts to resolve the dispute-causing acts of misuse of personal data of online transportation service users can be made through deliberations, arbitration and courts. The three forms of settlement are in accordance with Article 45 Paragraph (1), (2) of the Indonesian Basic Agrarian Law and Article 6 of the Arbitration Law. Regarding the act of arbitrary canceling the use of online transportation services by service users appears a crucially urgent object to be studied from a legal perspective in the next studies.
\end{abstract}

Keywords: Personal Data; Legal Protection; Online Transportation 


\section{PENDAHULUAN}

Pada era saatini, masyarakat Indonesia kian hari menginginkan perubahan dalam hidup mereka, mulai dalam gaya berpakaian sampai pada gaya hidup dalam aktivitas-aktivitasnya agar beroperasi secara instan. Keinginan masyarakat untuk mengikuti cara dan gaya kehidupan orang barat atau luar negeri memicu perubahan yang semakin hari terjadi semakin pesat pada setiap inividu. Pada era globalisasi ini, hal ini diakui kebenarannya. Pada masa globalisasi juga agar suatu Negara dapat beradaptasi dengan perkembangan dan kemajuan negara-negara lainnya, negara tersebut harus memenuhi tiga syarat mendasar, yaitu perlindungan hak atas harta individu, bidang-bidang pasar,dan persaingan bisnis yang sehat (Atmasasmita, 2014). Semakin lama perkembangan teknologi, khususnya internet, semakin menyebar secara menyeluruh ke dunia hingga ke Indonesia. Akibatnya, pengguna teknologi informasi internet di Indonesia menjelang tahun 2014 meningkat secara drastis (Sitompul, 2004).

Selain media komunikasi dalam bentuk internet, masyarakat memiliki dan menggunakan telepon seluler yang berfungsi sebagai sarana untuk mempermudah kegiatan masyarakat, seperti memperoleh barang dan jasa dalam waktu yang lebih singkat (Schwab, 2016; Daeng dkk., 2017; Koyoga, 2015). Layanan antar-jemput makanan, berbelanja kebutuhan pribadi dan keluarga, antar-jemput barang, hingga mencari kendaraan untuk pergi keluar rumah pada jaman sekarang dapat dilakukan hanya dengan mengaksesnya secara online menggunakan platform aplikasi yang telah didesain khusus untuk melakukan kegiatan tersebut. Proses untuk mendapatkan sesuatu yang diinginkan, produk atau jasa, berlangsung dengan canggih karena dilakukan hanya dengan jari untuk mengkases menu-menu aplikasi di telepon genggam atau gawai. Kendatipun begitu, seluruh aplikasi secama itu tidak didesain oleh penyedia produk atau jasa, atau dengan kata lain aplikasi ini disediakan dan dikelola oleh pihak ketiga yang menghubungkan antara penyedia produk atau jasa dengan penggunanya.

Sebagai salah satu persyaratan, setiap pengguna jasa atau produk yang ditawarkan melalui platform online diwajibkan untuk mendaftar atau setidaknya mengisikan identitasnya dan pada saat pengguna menyetujui untuk menggunakan jasa aplikasi online ini mereka diwajibkan untuk membiarkan aplikasi tersebut untuk mempunyai akses terhadap data-data pribadi mereka yang lain, seperti email, kontak yang ada dalam gawainya hingga informasi lokasi keberadaan gawai tersebut. Sayangnya, kecanggihan ini terkadang disalahgunakan untuk bertindak tidak baik kepada pengguna atau konsumen pemilik identitas dimaksud (Pratama dkk., 2016). Sementara, Undang-Undang Pokok Agraria (selanjutnya disebut UUPK) negara Indonesia menetapkan bahwa hak-hak konsumen harus memiliki kepastian dan jaminan (Sidabalok, 2006). Dengan eksistensi UUPK pemilik usaha bisa terpacu untuk meningkatkan daya saingnya dengan mengutamakan kepentingan konsumen. Salah satu pelaku usaha berbasis teknologi dibidang jasa layanan transportasi di Indonesia ialah Grab.

Grab adalah sebuah entitas pelaku usaha yang bertujuan untuk meningkatkan dan mengembangkan industri dalam bidang transportasi. Grab bekerjasama dengan pengemudi-pengemudi yang memiliki pengalaman. Adanya jasa layanan ini sangat mempermudah berbagai kegiatan masyarakat yang cenderung tidak ingin repot serta ingin menghemat waktu. Saat Grab memberikan pelayanannya, transportasi yang digunakan adalah kendaraan dalam wujud sepeda motor dan mobil, sebagaimana kendaraan umum yang digunakan sebagai alat transportasi. Menurut UU No. 22 Tahun 2009 tentang Lalu Lintas dan Angkutan Jalan (selanjutnya disebut LLAJ), yang dimaksud dengan kendaraan ialah mesin yang menggerakan benda dan rutenya tidak dijalankan diatas rel.

Konsumen atau masyarakat yang ingin mencari jasa Grab tidak lagi harus melakukannya dengan cara yang konvensional, menunggu di setia pujung pangkalan atau tepi jalan. Dengan cara yang modern, setiap orang yang membutuhkan jasa transportasi dapat memperolehnya hanya dengan menekan beberapa tombol yang ada di gawai mereka, lalu pihak penyedia layanan akan mencarikan pengemudi dan setelah ditemukan pengemudi akan menemui pengguna jasa. Bukan saja proses pemesanan ini yang menjadi mudah, para pengguna atau pemeran jasa transportasi online juga dipermudah untuk mengenali para pengemudi yang akan menjemput mereka serta dapat berkomunikasi dengan mereka melalui fiturfitur chat atau obrolan dan telepon yang tersedia dalam aplikasi. Dengan demikian, kespakatan atau ketidak sepakatan antara calon pengguna jasa transportasi dan pengemudi pun dapat dilakukan.Artinya, bila calon pengguna jasa atau pengemudi menemukan kendala, pemesanan dapat dibatalkan melalui kesepekatan yang dilakukan melalui komunikasi. Kemudian, apabila penggunaan jasa transportasi telah selesai, para pengguna diharapkan untuk memberikan penilaian melalui pemberian ulasan atas jasa yang telah diterima. Ini menunjukkan bahwa pelayanan Grab sebagai salah satu penyedia jasa transportasi 
online lebih memberikan jaminan mutu pelayanan dibandingkan dengan jasa transportasi lain yang beroperasi secara konvensional. Karena kecanggihannya jasa transportasi initerkenalsecara luas dikalangan masyarakat, khususnya di kota besar yang telah memiliki akses jaringan internet.

Untuk dapat mendapatkan jasa tersebut layanan internet diperlukan. Dengan demikian, penggunaan layan ini dapat dilakukan dilakukan kapan dan di mana saja sepanjang akses internet telah tersedia. Di Indonesia, layanan internet telah menyentuh hampir seluruh daerah, terutama di pusat-pusat kota dan daerah yang telah dilintasi sarana dan prasana transportasi. Sayangnya, kecanggihan dan kemudahan yang diberikan melalui aplikasi ini juga meningkatkan resiko bagi pengguna atau konsumennya. Akibat semakin berkembangnya sector bisnis dalam transportasi umum, perlindungan hukum yangada belum memiliki kekuatan yang memadai untuk mengatur segala tindakan ataupun ketentuan sanksi dalam bidang tersebut seperti perlindungan hukum terhadap data pribadi konsumen, termasuk konsumen layanan Grab. Hal ini karena risiko yang dapat terjadi pada pengguna jasa tersebut terwujud dalam berbagai macam, intimidasi terhadap pengguna yang telah memberi ulasan yang buruk (Tejomurti dkk., 2018). Salah satu tindakan yang lakukan kepada pengguna jasa transportasi online ialah penyalahgunaan data pribadi yang dibagikan melalui aplikasi online. Setiap proses transaksi jasa transportasi online menyaratkan permintaan informasi tentang data pribadicalon pengguna jasa guna mempermudah akses penyaluran jasa tersebut. Di masyarakat, dengan memberikan data pribadi ini maka dirasa akan timbul risiko barubagi pemilik data tersebut. Penyalahgunaan data pribadi terjadi karena jika dilihat dari prosedur pemesanan layanan Grab ini dengan memasukkan data pribadi pengguna berupa nama dan nomor telepon serta email, dan melanjutkan untuk memesan layananya, maka data pribadi pengguna akan terlihat pada telepon seluler yang dipegang oleh pengemudi grab yang telah ditugaskan, selain itu tujuan pengguna juga akan terlihat pada telepon pengemudi tersebut.

Selain itu, setiap pengemudi yang telah ditugaskan oleh Grab untuk menjemput konsumen akan memastikan kembali kepada konsumen kebenaran telah memesan jasa Grab atau tidak dan titik penjemputan yang sesuai dengan aplikasi. Dengan demikian, secara tidak langsung pengemudi bisa mengetahui nomor pribadi si pemesan jasa dan pengemudi juga dapat mengetahui alamat yang dituju atau penjemputannya yang biasanya dari rumah. Hal ini bisa dikatakan bahwa apabila pengemudi bertugas, pengemudi tersebut mengetahui data pribadi si pengguna jasa tersebut. Sebenarnya tidak masalah bila pengemudi mengetahui data pribadi dari konsumen tersebut asalkan dipergunakan selayak semestinya. Akan tetapi dalam hidup ini semua kesempatan ini dapat disalahgunakan untuk tujuan dan kepentingan personal yang tentu menimbulkan resiko berupa kerugian-kerugian bagi pihak tertentu. Penyalahguaan tersebut dapat merugikan pihak pengguna jasa Grab dan merasa privasinya terganggu.

Berdasarkan latarbelakang di atas, masalah pokok yang perlu diteliti adalah1) Bagaimanakah bentuk perlindungan hukum terhadap konsumen pengguna jasa transportasi online atas penyalahgunaan data pribadinya? 2) Bagaimanakah upaya yang dilakukan konsumen pengguna jasa transportasi online apabila data pribadinya disalahgunakan? Tujuan di penelitian mengungkap bentuk perlindungan hukum atas penyalahgunaan data pribadi pengguna jasa transportasi online dan tanggungjawab hukum oleh pelaku penyalahgunaan dimaksud serta menggambarkan upaya yang dapat dilakukan oleh korban penyalahgunaan data pribadi dalam layanan transportasi online di Indonesia.

\section{METODE PENELITIAN}

Pencarian informasi secara normatif berpatokan pada peraturan pemerintah yang berfokus pada objek analisis dalam informasi yang diperoleh secara konseptual berkaitan dengan kajian ini. Penelitian ini mengunakan desain dan metode penelitian hukum normatif. Penelitian hukum normatif merupakan kajian kepustakaan yang memanfaatkan norma-norma hukum yang terdapat dalam peraturan perundangundangan sebagai datanya. Di samping itu, penelitian ini dilakukan dengan menerapkan pendekatan perundang-undangan (statute approach) dan pendekatan kasus (case approach). Penelitian ini mempunyai dasar pelaksanaan yaitu undang-undang negara Republik Indonesia yang mengatur tentang transaksi online.

Dalam kaitan dengan pendekatan kasus, penelitian ini dilakukan dengan mengidentifikasi, mencatat, dan memahami masalah menurut sudut padang hukum positif. Data-data yang digunakan dalam penelitian adalah pasal-pasal Undang-Undang yang berlaku Indonesia, seperti Undang-udang Dasar Negara Kesatuan Republik Indonesia (NKRI) 1945, Undang-Undang Nomor 11 Tahun 2008 tentang Informasi dan Transaksi Elektronik, dan Peraturan Pemerintah (PP) nomor 71 tahun 2019 tentang 
Penyelenggaraan Sistem dan Transaksi Elektronik (PP PSTE). Penulis menelitikasus penyalahgunaan data pribadi pengguna jasa transportasi online menggunakan metode normative dengan menelaah isu hukum yang didasari pada peraturan-peraturan hukum di Indonesia (Ahmad, 2008). Pertama-tama, fenomena penyalahgunaan data pribadi pengguna jasa transportasi online, khususnya Grab, diidentifikasi.

Kemudian, Undang-Undang yang berlaku dan mengatur sektor transportasi online ditemukan dan diidentifikasi. Setelah itu, Setelah itu, analisis dilakukan pada Undang-Undang yang telah ditemukan untuk menentukan bentuk-bentuk hukum yang berfungsi melindungi para pengguna jasa transportasi online apabila data pribadi mereka disalahgunakan. Selain itu, mengacu dan berkaitan dengan UndangUndang yang mengatur tentang transaksi online yang meliputi kewajiban dan hak-hak penyedia dan pengguna, upaya-upaya yang dapat dilakukan oleh pengguna jasa transportasi online apabila penyalahgunaan atas data pribadi mereka terjadi, kemudian, ditelaah dan dirumuskan. Hasil dari analisis kemudin disajikan secara deskriptif informal. Pada tahap terakhir, simpulan-simpulan dari penelitian ditarik serta rekomendasi-rekomendasi terkait masalah transportasi online diberikan untuk berbagai pihak yang berkaitan.

\section{HASIL PENELITIAN DAN PEMBAHASAN \\ Pelindungan Hukum terhadap Data Pribadi Pengguna Jasa Transportasi Online Berdasarkan Undang-Undang Nomor 11 Tahun 2008 tentang Informasi dan Transaksi Elektronik}

Salah satu kewajiban suatu Negara ialah memastikan bahwa setiap warga negaranya membentuk payung hukum yang tepat seperti yang disebutkan dalam UUD NKRI 1945 yang menjelaskan bahwa Negara Indonesia berlandaskan hukum. Setiap warga Negara yang baru lahir sudah mendapatkan hak asasi manusia dan hak-haknya sebagai manusia. Adanya payung hukum ini diharapkan agar setiap warga Negara mendapatkan fasilitas untuk mendapatkan hak asasi manusia apabila dikemudian hari timbul masalah yang diakibatkan oleh pihak ketiga bertujuan agar setiap masyarakat dapat menjalankan hak dan kewajibannya sebagai warga Negara Indonesia (Rahardjo, 2000). Berkaitan dengan konsumen, Negara Indonesia menyediakan fasilitas berlandaskan hukum untuk hak warga negaranya apabila tidak terpenuhi (Hadjon, 1987). Hak asasi manusia ialah sumber dari konsep tindakan pemerintah untuk dapat membantu mendapatkan posisi padahal dan kewajiban.

Perkembangan teknologi menawarkan dua sisi kepada masyarakat dan kehidupannya, seperti sisi positif dan sisi negatif. Kehadiran teknologi canggih mengkonfirmasikan bahwa tindakan penyalahgunaan tidak hanya terjadi pada aspek-aspek yang adalah dalam dunia tetapi juga pada aspek yang berbentuk virtual atau dunia maya. Kehadiran transportasi online, seperti gojek, yang beroperasi secara online mempunyai manfaat yang efisien karena mampu mempermudah kegiatan masyarakat serta menghemat biaya. Sayangnya, kesempatan ini ternyata dapat dimanfaatkan untuk fungsi lain yang memicu terjadinya bentuk kejahatan baru. Data pribadi pengguna jasa transportasi online ternyata dapat dimanfaatkan oleh pihak-pihak tertentu yang mempunyai terhadapnya atasnya. Kemunculan ini pun bukan sebuah hal yang dapat dipungkiri. Hal yang perlu dilakukan ialah bagaimana mengatasi hal itu, termasuk bagaimana mengantisipasi dan prosedur apa yang harus dilakukan apabila sudah terjadi.

Berkaitan dengan penyalahgunaan data pribadi pengguna jasa transportasi online, khususnya Grab, dari perspektif hukum ini bisa dikaji menurut Undang-Undang Nomor 11 Tahun 2008 tentang Informasi dan Transaksi Elektronik and Undang-Undang Nomor 8 Tahun 1999 tentang Perlindungan Konsumen. Dalam Pasal 1 angka 2 Undang-Undang tersebut ditetapkan bahwa Transaksi Elektronik merupakan perbuatan hukum yang dilakukan dengan menggunakan komputer, jaringan komputer, dan/atau media elektronik lainnya. Dalam konteks semacam ini, terjadi hak dan kewajiban baik bagi penyedia jasa maupun penggunanya. Kemudian, dalam angka 1 Undang-Undang tersebut ditentukan bahwa informasi elektronik merupakan suatu atau sekumpulan data elektronik, termasuk tetapi tidak terbatas pada tulisan, suara, gabmar, peta, rancangan, foto, electronic data interchange (EDI), surat elektronik (electronic mail), telegram, teleks, telecopy atau sejenisnya, huruf, tanda, angka, kode akses, simbol, atau perforasi yang telah diolah yang memiliki arti atau dapat dipahami oleh orang yang mampu memahaminya.

Serangkaian informasi personal yang diberikan oleh pengguna jasa ke dalam aplikasi jasa transportasi online Grab yang meliputi alamat nama, email, nomor telepon, dan kadang-kadang informasi akun media pembayaran termasuk dalam lingkup data yang dimaksud dalam Pasal 1 angka 1 UU Nomor 
11 ITE Tahun 2008 (UNTAD, 2016; Rosadi \& Tahira, 2018; Anugerah \& Indriani, 2018). Data pribadi yang diberikan oleh konsumen saat mendaftar pada aplikasi mobile transportasi online yang kemudian tersimpan dalam sistem informasi transportasi seluler onlie adalah bentuk informasi elektronik. Informasi ini digunakan oleh satu-satunya pengemudi transportasi seluler untuk melakukan pekerjaan mereka, yang meliputi menghubungi konsumen, mengetahui alamat dan posisi kehadiran pelanggan dan menyediakan layanan sesuai dengan layanan yang dipilih oleh konsumen (Pratama dkk., 2016).

Peraturan dibuat memiliki tujuan untuk melindungi masyarakat apabila di kemudian hari menimbulkan sengketa atau perbuatan hukum dan apabila dilanggar mememiliki hukumanya sendiri. Perlindungan hukum ialah hal yang melindungi subjek-subjek hukumnya dalam hal ini ialah konsumen yang memiliki data pribadi melalui peraturan perundang-undangan yang berlaku dan apabila dilanggar akan dikenakan suatu sanksi. Pelanggaran perlindungan data dapat dikenakan tanggung jawab administratif dan pidana di Indonesia. Sebagai aturan praktis, berdasarkan Peraturan Menkominfo 20, setiap orang yang mengumpulkan, memproses, menganalisis, menyimpan, mempromosikan, mengumumkan, mentransmisikan, atau menerbitkan data pribadi tanpa hak untuk melakukannya akan dikenakan sanksi administratif tertentu, seperti peringatan lisan; peringatan tertulis; penangguhan kegiatan; atau pengumuman di situs web yang relevan (Simpson \& Sotto, 2019).

Seperti yang disebutkan pada bagian sebelumnya proses transaksi dengan jasa transportasi online dengan Grab melibatkan konsumen melakukan pendaftaran yang mensyaratkannya memberikan datadata pribadinya melalui aplikasi Grab dan data tersebut berbentuk informasi elektronik. Data tersebut tersimpan di dalam aplikasi Grab. Setiap kali pengguna menggunakan jasa transportasi Grab, data pengguna yang telah terdaftar menjadi data yang digunakan untuk meyambungkan dengan pengemudi (Pratama dkk., 2016). Dengan data tersebut, pengemudi yang telah ditunjuk oleh Grab menghubungi pengguna untuk dapat melanjutkan proses pemberian jasa transportasi.

Hal ini terlihat sangat wajar dan seakan tidak memiliki risiko yang berarti. Sayangnya, kenyataan tidak sejalan dengan harapan. Terjadi situasi yang meragukan terkait data-data pengguna yang telah terinput dalam aplikasi Grab tersebut. Dengan alas an yang berbeda, data-data tersebut dapat dijadikan alat untuk menakut-nakuti pengguna jasa transportasi tersebut apabila member ulasan yang buruk atas pelayanan yang telah pengguna terima (Pratama dkk., 2016; Hadi dkk., 2019). Selain itu, hal lain bisa terjadi seperti data pengguna digunakan untuk melakukan peminjaman uang online. Tindakan-tindakan penyalahgunaan semacam ini merupakan bentuk penyelewengan penggunaan data dan informasi konsumen tanpa konsumen bersangkutan mengetahui apapun tentang hal itu. Di Indonesia kerahasiaan data konsumen ini dilindungi oleh Undang-Undang. Apabila dilanggar, tindakan tersebut melanggar ketentuan Pasal 26 UU ITE tentang Data Pribadi dan ketentuan tentang Hak Konsumen yang tertuang dalam Pasa 4 Huruf a dan d Undang-Undang Perlindungan Konsumen (Widijowati dkk., 2019).

Meskipun sebenarnya belum ada perlindungan hukum yang secara khusus untuk melindungi datadata elekteronik, terdapat aturan hukum yang dapat dijadikan pedoman untuk mengimplementasikan jaminan dan perlindungan bagi warga Negara, terutama terkait dengan data pribadi elektronik (Rosadi, 2018). Bentuk Perlindungan hukum untuk data pribadi elektronik dibedakan menjadi dua macam yakni bentuk perlindungan hukum preventif dan bentuk perlindungan hukum represif (Muchsin, 2003). Bentuk perlindungan hukum reventif didominasi oleh tindakan pemerintah untuk mencegahnya suatu sengketa di kemudian hari. Hal ini biasa dilakukan dengan sosialisasi atau himbauan kepada masyarakatnya. Sedangkan bentuk perlindungan hukum represif adalah suatu tindakan untuk menyelesaikan sengketa yang sudah terjadi melalui meja hijau atau pengadilan atau litigasi. Masyarakat Indonesia membutuhkan kejelasan peraturan yang berlaku karena dapat mengarahkan warga Indonesia menjadi lebih aman, baik dan tertib serta dapat melindungi hak dan kewajiban setiap individu dan dapat membantu mencapai tujuan dari peraturan pada umumnya seperti menciptakan aman, tentram, damai, sejahtera, dan adil. Segala aturan yang tertulis maupun tidak tertulisakan menjadi panutan bagiwarga Negara yang hidup pada Negara tersebut. Dewasa ini, akibat canggihnya sistem elektronik yang dapat mempermudah setiap kegiatan individu dari mendapatkan pelayanan hingga mudahnya mengumpulkan data yang dibutuhkan khususnya data pribadi menimbulkan keresahan pada pengguna jasa layanan atas penyalahgunaan informasi yang bersifat pribadi mereka pada internet. Peraturan delegasi dari UUITE yakni PPPSTE, menyebutkan segala data yang dijaga dan dipelihara rahasianya ialah arti dari data pribadi (Maskun, 2013). Jadi dapat disimpulkan bahwa data pribadi konsumen adalah biodata mereka sendiri. 
Upaya yang Dapat Dilakukan Korban Penyalahgunaan Data Pribadi pada Jasa Transportasi Online Faktor utama dalam transaksi online adalah kesepakatan yang berbentuk elektronik. Apa yang dimaksud dengan hal tersebut adalah media yang berbentuk digital. Berikut beberapa keunggulan dari menggunakan kesepakatan online ialah dari segi perusahaan meningkatkan efisiensi dan dari segi perorangan dapat menjalankan usahanya semakin luas dan mendapatkan peluang yang banyak yang dibuktikan dari aktivitas mereka menjadi lebih mudah dalam menawarkan kerjasama terhadap pihak lain. Kemudahan yang diberikan dari sistem internet ini ialah peluang besar untuk bekerjasama antar kota hingga ke seluruh dunia. Akibat dari kemudahan tersebut, perjanjian online mengalami peningkatan peminat walaupun tanpa melihat para pihak satu sama lain seperti perjanjian biasanya. Akan tetapi, meningkatnya jumlah peminat penggunaan jasa transportasi online menyiratkan perlunya perlindungan hukum. Sayangnya, dalam kecanggihan tersebut masih belum dapat terlindungi transaksi maupun para pihak secara menyeluruh akibat tidak adanya aturan yang mengatur khususnya pada syarat utama menjalankan aplikasi dengan memberikan data pribadi dan maraknya penyalahgunaan informasi dalam kehidupan nyata. Dapat dikatakan bahwa pemerintah dan pelaku usaha perlu merencanakan untuk menerbitkan aturan mengenai privasi tersebut.

Sembari menunggu peraturan dibuat dan diterbitkan, perlunya tindakan sosialisasi dari pemerintah untuk menghimbau masyarakat dan meminimalisisr tindak pidana penyalahgunaan data privasi tersebut. Berdasarkan uraian di atas maka bentuk peraturan konsumen jasa transportasi online berbentuk adanya aturan tertulis di mana kendaraan online masuk ke dalam bidang transaksi online maka bentuk perlindungan hukumnya represif, pengguna jasa layanan transportasi online dapat melakukan gugatan perdata kepada pihak penyelenggara jasa layanan transportasi online dan pengguna jasa layanan bisa mengajukan gugatan secara pidana terhadap pengendara/pengemudinya langsung tanpa beratasnamakan penyelenggara jasa layanan transportasi online. Walaupun pengemudi diberikan akses untuk mengetahui data privasi konsumen akan tetapi mereka tidak boleh bertindak sewenang-wenang kehendak pribadinya, sehingga untuk meminimalisir kejadian yang tidak diinginkan maka pihak penyedia layanan memberikan sanksi kepada pengemudi apabila mereka bertindak di luar batas wajarnya dengan memberikan peringatan hingga pemblokiran akun di mana pengemudi tersebut tidak akan bisa aktif menjadi pengemudi lagi. Apabila konsumen ingin melaporkan kejahatan yang dilakukan pengemudi, itu dapat dilakukan dengan mengajukan gugatan terhadap pengemudinya.

\section{SIMPULAN DAN SARAN}

\section{Simpulan}

Bentuk perlindungan hukum terhadap konsumen pengguna jasa transportasi online atas penyalahgunaan data pribadinya ialah berbentuk perlindungan hukum represif, pengguna jasa layanan transportasi online dapat mengajukan gugatan perdata kepada pihak penyelenggara jasa layanan transportasi online dan pengguna jasa layanan bisa mengajukan gugatan secara pidana terhadap pengendara/pengemudinya langsung tanpa beratasnamakan penyelenggara jasa layanan transportasi online. Kemudian, upaya yang dapat dilakukan konsumen pengguna jasa transportasi online apabila data pribadinya disalahgunakan dan menimbulkan sengketa antara penyedia transportasi online, pengemudi, dan konsumen dapat dilakukan dengan cara musyawarah, arbitrase dan pengadilan. Ketiga cara penyelesaian sengketa ini sesuai dengan Pasal 45 Ayat (1), (2) UUPK dan Pasal 6 Nomor 30 Tahun 1999 UUPK.

\section{Saran}

Berdasarkan simpulan tersebut di atas, beberapa rekomendasi adalah: pemerintah sudah seharusnya menetapkan Undang-Undang yang mengatur secara khusus mengenai penyelenggara jasa transportasi online agar data pribadi dan privasi konsumen terlindungi; perusahaan transportasi online perlu melakukan seleksi ketat untuk calon pengemudi demi meminimalisir terjadinya hal-hal yang dapat merugikan konsumen; dan konsumen hendaknya membaca dan memahami isi kontrak elektronik ketika hendak menggunakan aplikasi untuk mengurangi risiko pelanggaran terhadap data pribadi oleh pihak lain.

\section{DAFTAR PUSTAKA}

Ahmad, B. (2008). Metode Penelitian Hukum. Pustaka Setia.

Anugerah, D. P., \& Indriani, M. (2018). Data Protection in Financial Technology Services (A Study in 
Indonesian Legal Perspective). Sriwijaya Law Review, 2(1), 82-92. https://doi.org/10.28946/slrev.vol2.iss1.112.pp82-92

Atmasasmita, R. (2014). Hukum Kejahatan Bisnis: Teori dan Praktik di Era Globalisasi. Predana Media. Daeng, I. T. M., Mewengkang, N. N., \& Kalesaran, E. R. (2017). Penggunaan Smartphone dalam Menunjang Aktivitas Perkuliahan oleh Mahasiswa Fispol Unsrat Manado. E-Journal Acta Diurna, $6(1), 1-15$.

Hadi, H., Tejomurti, K., Imanullah, M. N., \& Nurhidayatuloh. (2019). Online Transportation: Violation of Privacy Rights and Vulnerability to Sexual Violence by Drivers in Digital Platform-Based Work. Advances in Social Science, Education and Humanities Research, November, 241-246. https://doi.org/10.2991/icglow-19.2019.61

Hadjon, P. M. (1987). Perlindungan Hukum Bagi Rakyat Indonesia. Bina Ilmu.

Koyoga, D. (2015). Dampak Penggunaan Handphone pada Masyarakat: Studi pada Masyarakat Desa Piungun Kecamatan Gamelia Kabupaten Lanny Jaya Papua. Acta Diurna, 4(4).

Maskun. (2013). Kejahatan Siber (CyberCrime). Kencana Prenada Group.

Muchsin. (2003). Perlindungan dan Kepastian Hukum Bagi Investor di Indonesia. Magister Ilmu Hukum Program Pasca Sarjana Universitas Sebelas Maret.

Pratama, G. Y., Suradi, \& Aminah. (2016). Perlindungan Hukum terhadap Data Pribadi Pengguna Jasa Transportasi Online dari Tindakan Penyalahgunaan Pihak Penyedia Jasa Berdasarkan UndangUndang Nomor 8 Tahun 1999 Tentang Perlindungan Konsumen. Diponegoro Law Journal, 5(3), $1-19$.

Rahardjo, S. (2000). Ilmu Hukum. PT. Citra Aditya Bakti.

Rosadi, S. D. (2018). Protecting Privacy on Personal Data in Digital Economic Era : Legal Framework in Indonesia. Brawijaya Law Journal, 05(01), 143-157. https://doi.org/10.21776/ub.blj.005.01.09

Rosadi, S. D., \& Tahira, Z. (2018). Consumer Protection in Digital Economy Era: Law in Indonesia. Mathematics Education Journal, 7(1), 85-97. https://doi.org/10.29333/aje.2019.423a

Schwab, K. (2016). The Fourth Industrial Evolution. In World Economic Forum (Issues 1-177). https://doi.org/10.1017/CBO9781107415324.004

Sidabalok, J. (2006). Hukum Perlindungan Konsumen di Indonesia. Citra Aditya Bakti.

Simpson, A. P., \& Sotto, L. J. (2019). Data Protection \& Privacy - 2020. In Law Business Research. Law Business Research.

Sitompul, A. (2004). Internet Pengenalan Mengenai Masalah Hukum di Cyberspace. Citra Aditya Bakti.

Tejomurti, K., Hernawan, H., \& Imanullah, Moch. Najib Indriyani, R. (2018). Legal Protection for Urban Online-Transportation Users' Personal Data Disclosure in the Age of Digital Technology. Padjajaran Jurnal Ilmu Hukum, 5(3), 485-505.

UNTAD. (2016). Data protection regulations and international data flows: Implications for trade and development. United Nations Conference on Trade and Development, 1-154.

Widijowati, R. D., IdwanMariza, P., \& Loin, R. (2019). Analysis Juridical of Transactions Through the Internet (E-Commerce) Related with Consumer Protection Law. KnE Social Sciences, 3(14), 491505. https://doi.org/10.18502/kss.v3i14.4333 